\title{
An investigation into factors that determine the growth rate in the Islamic banking and finance
}

Huma Nawaz ${ }^{1,2 *}$ D

\begin{abstract}
The purpose of this study is to determine the impact of products and services of Islamic finance in Pakistan. This study has involved an empirical analysis of the environmental factors of growth and its impact on the growth of Islamic Financial Institutions. To investigate the factors of growth, a structural equation model develops that incorporates the main determinants of growth of banking assets and equity funds. The growth in the Islamic equity funds and banking assets has been identified as definite antecedents of growth in the Islamic financial system. The empirical investigation by the structural model using Pakistani dataset revealed that four out of ten hypotheses were significant including two direct paths as antecedents of annual growth. This study provides empirical support for the influence of some development factors to control the barriers of growth in the Islamic finance industry. This paper allows the identification of the major development factors of Islamic financial system that takes into account the importance of operational strategy and environment for the growth of Islamic equity funds and banking assets.
\end{abstract}

Keywords: Structural equation model, Ethical finance, Islamic financial system, Islamic products and services, Growth, Islamic banking, Islamic equity fund, Pakistani finance

JEL Classification: G10, G14, G15G17, G21

\section{Introduction}

The first, experimental, local Islamic bank was established in the late 1950s in a rural area of Pakistan which charged no interest on its lending [53]. However, since then the Islamic financial development has been slow and poorly developed as the result of a strong foothold in the conventional financial system. The developmental measures still could not bring them to the extent of competing strongly with an interest-based system. In fact, the Islamic finance market is often referred to as a "niche market".

A country needs to maintain a positive direct relationship with the financial organization for financial growth. However, some inadequate financial policies and decisions based on conventional interest system

\footnotetext{
*Correspondence: huma.humanawaz@outlook.com

${ }^{2}$ Islamia University Bahawalpur, Bahawalpur, Pakistan

Full list of author information is available at the end of the article
}

were incapable of functioning both effectively and ethically within the society, consequently resulting in a weak financial system with meager outcomes.

Population, time interval, return, and economic parameter, i.e., Gross domestic product (GDP) growth rate are an important consideration for development of Islamic banking and equity fund industry. Many Islamic banking and finance studies $[1,2,11,27,65]$ explored factors of growth. However, existing literature on Islamic finance investigated only one class of Islamic financial system, among many instruments, i.e., Islamic equity funds, Islamic finance assets, Islamic equity capital, Islamic capital market instruments, Islamic loan funds, Islamic bank deposits and financial returns of participating Islamic banks.

Moreover, the vast literature on Islamic banking and finance on factors of growth is rooted in the developed countries, leaving the impact of major emerging markets almost unexamined. These gaps in the study are 
not acknowledged, therefore, an extension of research in comparison to growth components of sample size could be extended for determination of important development tools.

\section{Background of theory and hypothesis development}

In an Islamic financial system framework, all the principles, laws, and process follow a commitment to Allah and His last prophet Muhammad (PBUH). Moral soundness applied for acceptance of financial transactions, contract, or instruments [39]. Methodology for theory building in Islamic economics based on economic statements of the Quran, Hadith, and Sunnah lead to method that unfolds a mechanism to arrive at the real and undeniable meanings for development of the Islamic economic system [38].

Recent literature is drawing theoretical aspects of Islamic banking and finance for depositors, regulators, owners, managers, and borrower of the Islamic financial system. However, theoretical aspect of this study is based on socioeconomic theory.

Islamic economic theory and traditional economic theory are two different approaches. Both theories have different perspectives. "The principle of contractual fairness could counterbalance the principle of permissibility with the objective of attaining social justice or equity between the parties" [8].

The theoretical framework builds upon the basis of external and internal variables that effect on an Islamic financial system, with many variables including, banking as the endogenous variable and four constructs of the exogenous variable, i.e., return, population, time interval, and Gross domestic product (GDP) growth rate. The conceptual framework for the hypothesis is depicted in Fig. 1.

Prohibition of Riba (interest) is a core component of the Islamic economic theory. For financial matters, gains through fair trade are legitimized in the canon

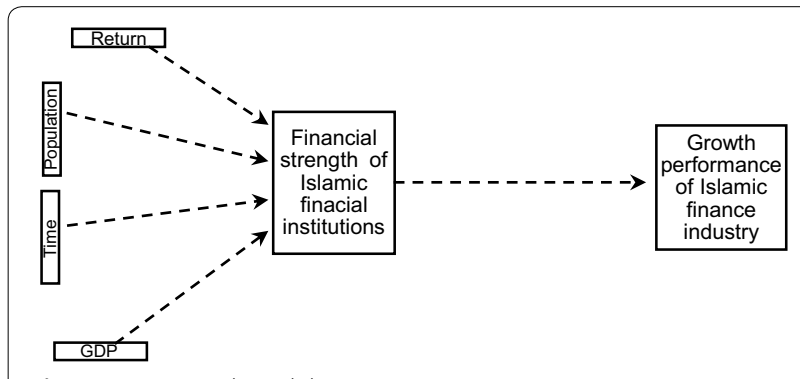

Fig. 1 Conceptual model but are offset by the prohibitions of Riba (interest/ usury), maysir (gambling) and gharar (excessive risk or uncertainty) [63].

The macroeconomic variable, inflation rate (INF), has a negative and statistically significant impact on the ROE for both domestic and foreign banks. Therefore, high INF is associated with low ROE of banks.

There are many reasons for the study based on the determinants of growth of the Islamic financial system. According to the socioeconomic theory, income and well-being of the people are components of social economy perspectives [18]. The demand for social justice and economic opportunity lead to the developmental growth of Islamic economic and financial ideas [30].

Normally, Islamic banking is less risky due to profit and loss sharing features of their banking services. On the other hand, conventional banking systems are exposed to more risk due to certain economic turmoil, i.e., by an increase in inflation.

The variables of underlying study, i.e., return (income), population, time interval, and Gross domestic product (GDP) have been extended for country dataset.

The impact of performance of Islamic equity funds and Islamic banking assets is also an interesting issue to examine as the basis of the country instead of traditional investments, the banking system, and socially responsible investment funds (SRI) or ethical equity funds. Several researchers such as Azhar Rosly and Afandi Abu Bakar [7], Akhtar et al. [3], Siddiqui [60], Moin [43], Sadeghi [54], and Subramaniam et al. [61] have individually investigated this issue and it was to be put into effect in different regions of the world.

The profit is the difference between the revenue and cost while investment is an investment of project and cost is general cost and cost of fund. In general, Islamic profit and loss sharing have no interest cost and cost of fund. However, a higher return is an important prerequisite for above average profitability of financial system [50].

To determine how banking systems view increased participation with regard to the growth of Islamic financial system, Keith G. Carr-Lee, B.A. surveyed and compared Islamic banking sectors to those without such sectors. The researcher analyzed data from over 26 Organization of Islamic Cooperation (OIC) states of majority in Muslim populations. The researcher found the growth of an existing Islamic banking sector is directly related to countries that already possess Islamic financial system and have a positive effect on the rate of growth of financial depth [19].

Nainggolan [46] found that younger fund performed better than older funds, researcher concluded that 
there is a positive relationship between fund size and performance [46].

Perception and awareness in Islamic countries observed as an important aspect of Islamic finance growth. However, in spite of the similarity in GDP rate of Islamic and non-Islamic countries, Islamic banking sector showed a key development indicator with an increase in its product awareness [57].

The aim of this research is to investigate factors of growth in Islamic financial system in Pakistan and to determine how these factors are related to the development of Islamic financial products and services-i.e., the degree to which Islamic banking assets and Islamic equity funds act as an important factor in the Islamic financial industry growth. More significantly, this paper is answering the research question, i.e., "What are the development factors of growth of Islamic financial system and how do they influence the Islamic financial system?" While the following hypothesis has been developed for this study based on the literature and conceptual framework described in Fig. 1 and next section, respectively.

$\mathrm{H}_{1}$ There is a significant relationship between the volatility of Islamic banking assets and return $(R)$.

$\mathbf{H}_{2}$ Population $(P)$ has a direct effect on Islamic banking assets.

$\mathbf{H}_{3}$ Time interval $(T)$ has a direct effect on Islamic banking assets.

$\mathbf{H}_{4}$ GDP (GDP) has a direct effect on Islamic banking assets.

$\mathbf{H}_{5}$ There is a significant relationship between the volatility of NAV of Islamic equity funds and Return (R).

$\mathbf{H}_{\mathbf{6}}$ Population $(P)$ has a direct effect on NAV of Islamic equity funds.

$\mathbf{H}_{7}$ Time interval $(T)$ has a direct effect on NAV of Islamic equity funds.

$\mathbf{H}_{\mathbf{8}}$ GDP (D) has a direct effect on NAV of Islamic equity funds.

$\mathbf{H}_{\mathbf{9}}$ NAV of Islamic equity funds has a direct effect on the growth of Islamic financial system.

$\mathbf{H}_{10}$ Islamic banking assets have a direct effect on the growth of Islamic financial system.

\section{Methods}

According to Rani and Sikka [52], time series data have a significant size and can be organized into three groups, i.e., work directly with raw data in frequency or time domain, indirectly with the features either extracted from the model of raw data [52]. Two types of data either primary or secondary were gathered from experimental studies. This study is using time series data as a technique based on secondary data. Meanwhile, Bryman and Bell [16] stated that secondary data refer to the data, such as theoretical papers, and comparative research reports, and the grey literature is collected by other research scholars and institutions [16]. The secondary data were collected by reports of national and international institutions, research and articles based on operational efficiency.

To provide a solution to a research problem, traditional quantitative data were collected from each institutional respective entity. Due to limited resources, the author relied more on secondary data. To create the authenticity of this data, data have been extracted from Government monetary and international regulatory institutions of Pakistan. To create a deeper understanding of growth factors regarding Islamic financial institution in Pakistan, it has been necessary to take and observe speeches of institutional respective executives for a deeper understanding of growth factors. The perceived value of Internet surfing and its impact on reading practices and research has been approved by a number of studies [41].

The desired sample size for the complex structural model should be 200 or more [29]. Hence, dataset for this study have more than 200 observations. The sound judgment of data is an important component of research worth. Examination of data not only required to proceed data analysis but it also provides critical insight into data characteristics [26]. First, replacement of missing values with zero is the authentic solution for valid time series [9]. Missing data were replaced with zero due to the nonexistence of a respondent's operational activity during the sample period (2005-2015). Second, data pattern was identified for multivariate data items. Descriptive statistics including mean, standard deviation variance and skewness was conducted. Likewise, to reduce the skewness of data and to make the data pattern interpretable, $\log$ transformation $(\log 10)$ was performed [49].

The research objective implied the importance of research design and research method. Hence, diverse types of relevant research tools and instruments, necessary for analysis of data were collected for the accomplishment of this study objective.

The research of this study is conducted for evaluation of factors in relation to Islamic banking and finance. According to Creswell et al. [20] quantitative approach is best to identify factors that influence an outcome of 
an underlying problem, the utility of an intervention or identifying the best predictors of consequential outcomes [20]. Since the return, time interval, Muslim population, and GDP are difficult to measure by qualitative means, a quantitative approach would be more suitable to accomplish, the aim of this research.

A time series data of 11 years' (2005-2015) growth factors including time interval, GDP, income (return) and population, specific for this study was selected to analyze their impact on the development of Islamic finance in Pakistan. This study, therefore, uses time series as a technique based on the primary as well as secondary data. The randomly selected respondents who participated in this work are:

1. Meezan Bank Limited (MBL)

2. Dubai Islamic Bank Pakistan Limited (DIB)

3. Al Baraka Bank (Pakistan) Limited

4. Bank Islamic Pakistan Limited

5. Burj Bank Limited

\section{Equity funds}

Meezan equity fund

JS Islamic fund

Al Ameen Shari'ah Stock Fund

Alfalah GHP Islamic Stock Fund

Atlas Islamic Stock Fund

PIML Islamic Equity Fund

MCB Pakistan Islamic Stock Fund

Al Meezan Mutual Fund

HBL Islamic Stock Fund

ABL Islamic Stock Fund

The statistical process for calculation and analysis in Appendix was based on the following equations:

$$
\begin{aligned}
& \mathrm{IB}(\mathrm{PK})=\beta_{0}+\beta_{1} R+\beta_{2} P+\beta_{3} T+\beta_{4} \mathrm{GDP}+\text { eit, } \\
& E(\mathrm{PK})=\beta_{0}+\beta_{1} R+\beta_{2} P+\beta_{3} T+\beta_{4} \mathrm{GDP}+\text { eit, } \\
& \mathrm{G}(\mathrm{PK})=\beta_{0}+\beta_{1} I B(\mathrm{PK})+\beta_{2} E(\mathrm{PK})+\mathrm{eit},
\end{aligned}
$$

where GP is the growth of Islamic financial system in Pakistan and $\mathrm{IB}(\mathrm{PK})$ and $E(\mathrm{PK})$ is Islamic banks product and services (asset and equity fund NAV) development of Pakistan.

Independent variables are:

$$
\begin{aligned}
& R(\mathrm{PK})=\text { return } \\
& P(\mathrm{PK})=\text { population } \\
& T(\mathrm{PK})=\text { time interval }
\end{aligned}
$$

$$
\mathrm{GDP}(\mathrm{PK})=\mathrm{GDP}
$$

Mediating variables are:

$\mathrm{IB}(\mathrm{PK})=$ banking assets of Islamic banking of Pakistan

$E(\mathrm{PK})=\mathrm{NAV} /$ unit of Islamic equity fund of Pakistan

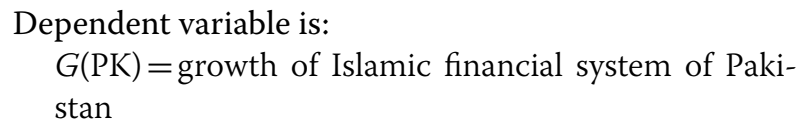

\section{Results}

\section{Assessment of normality (descriptive statistics)}

Table 1 (descriptive statistics of Pakistani dataset) shows the descriptive summary of the variables of this underlying study. It reflects mean, standard deviation, variance, skewness, and kurtosis of each variable, i.e., total banking assets, NAV and four factors of growth on selected Islamic banks of Pakistan. The mean $(M)$ is the average level of the variable data series. The variance is the variance of the time series around the mean.

Descriptive statistics suggest that the impact of variation in return $(M=7.61, \mathrm{SD}=.387)$ is more than the variations in GDP growth $(M=.532, \mathrm{SD}=.34)$. Precisely, data of Pakistan indicated that population $(M=8.23$, $\mathrm{SD}=.02)$ and return $(M=7.61, \mathrm{SD}=.387)$ have a higher impact compared to other independent factors underlying this study. The growth of equity fund is associated with the growth of Islamic financial system $(M=18.67$, $\mathrm{SD}=.66)$ to a great extent. While a positive relationship exists between equity $(M=2.84, \mathrm{SD}=.21)$ and growth of Islamic financial system $(M=18.67, \mathrm{SD}=.66)$, however, lesser than banking assets $(M=8.56, \mathrm{SD}=.28)$. A measure of variance shows that higher dispersion from data central tendency for a time interval (.101) and return (.150), respectively.

Table 1 Descriptive statistics of Pakistani dataset

\begin{tabular}{lcllc}
\hline Variables & $\begin{array}{l}\text { Mean }(\boldsymbol{M}) \\
\text { Statistic }\end{array}$ & $\begin{array}{l}\text { Std. deviation }(\text { SD) } \\
\text { Statistic }\end{array}$ & $\begin{array}{l}\text { Variance } \\
\text { Statistic }\end{array}$ & $\begin{array}{l}\text { Skewness } \\
\text { Statistic }\end{array}$ \\
\hline Time & .656 & .318 & .101 & -1.04 \\
Population & 8.23 & .02 & .001 & -.093 \\
Return & 7.61 & .387 & .150 & .427 \\
GDP & .532 & .34 & .116 & -2.779 \\
Assets & 8.56 & .28 & .079 & .88 \\
Equity & 2.84 & .21 & .046 & -2.560 \\
Growth & 18.67 & .66 & .43 & -.046 \\
\hline
\end{tabular}


The coefficient of skewness reflects the direction. Hence, the $(+)$ sign direction for positively skewed data and (0) sign reveals that the data are stable.

\section{Validity of constructs}

The sound judgment of quantitative research depends on the validity and reliability tests of an underline study. The authenticity and trustworthiness as an important component of a research evaluation are essential for selection of measurement techniques. Recognizing that all approaches to research have inherited limitations, however, biases inherent in any research lead to a decrease in the reliability and validity of result findings [35]. Therefore, reliability and validity of this study are provided with specifications of statistical tests.

The research objective implied the importance of research design and research method. Hence, diverse types of relevant research tools necessary for analysis of data. This was collected for research and significantly to the attainment of this study objective. The regression model has been a useful method for the analysis due to this study data property.

The Cronbach's alpha was used to investigate the reliability of the variables. Table 2 shows the reliability

Table 2 Reliability statistics of the scales, result of an analysis of the underlying variables of Pakistani dataset

\begin{tabular}{ll}
\hline Variables & $\begin{array}{l}\text { Cronbach's } \\
\text { alpha } \\
\text { coefficient }\end{array}$ \\
\hline Time & .200 \\
Population & .617 \\
Return & .605 \\
GDP & .620 \\
Assets & .614 \\
Equity & .602 \\
Growth & .166
\end{tabular}

coefficients of the data collected for each variable of Pakistani data sample. Moreover, results shows ranges from low to moderate coefficients level, i.e., .200 to .620 for Cronbach's alpha of underlying items, i.e., population, return, GDP, assets and equity results are at an acceptable level (>.6). However, the overall value of Cronbach's alpha is .604 , greater than .6 , which indicates an adequate level of acceptable internal consistency for this study sample.

\section{Validity test}

Before applying SEM, a factor analysis is necessary for the first stage of data analysis to summarize information of variables $[26,66]$. The validity test for all underlying items of Pakistani study sample is done using factor analysis as the basis. To condense the underlying variables of this study sample, principal component analysis was performed by undergoing Kaiser-MeyerOlkin (KMO) and Bartlett's test of sphericity to test its adaptability.

The results (Table 3) showed that the KMO measure of sampling adequacy $=.536$, which indicates that the reasoned analysis is reasonable [64]. Hair et al. [26] regards $\mathrm{KMO}=.5$ as suitable for factor analysis [26]. As for Bartlett's test of sphericity, the results in terms of Chi square distribution $\chi^{2}=69.51(d f=21$, Sig. $=.000)$ indicate that correlational matrix of study sample has common factors. Moreover, some scope for reducing the dimension exists for this sample dataset. After utilizing principal component analysis, the information in the third column of Table 3, indicates that all variable has a communality or variance of 1 . Factor 1 has an eigenvalue of 3.464 , which accounts for $49.491 \%$ of the total variance. While $26.671 \%$ of the total variance will be explained by the second factor. Moreover, $17.378 \%$ of the total variance will be explained by the third factor. Thus, only 3 components have an eigenvalue of 1 or greater and have a lot of variation and influence on Pcs.

Table 3 Total variance using principal component analysis

\begin{tabular}{lllllr}
\hline Variables & Factors & \multicolumn{2}{l}{$\begin{array}{l}\text { Communalities } \\
\text { Initial }\end{array}$} & & \multicolumn{3}{l}{ Initial eigenvalues } \\
\cline { 5 - 6 } & & 1.000 & Total & \% of variance & Cumulative \% \\
\hline Time & 1 & 1.000 & 3.464 & 49.491 & 49.491 \\
Population & 2 & 1.000 & 1.867 & 26.671 & 76.162 \\
Return & 3 & 1.000 & 1.216 & 17.378 & 93.540 \\
GDP & 4 & 1.000 & .319 & 4.560 & 98.100 \\
Assets & 5 & 1.000 & .100 & 1.429 & 99.529 \\
Equity & 6 & 1.000 & .027 & .392 & 99.921 \\
Growth & 7 & & & .079 & 100.000 \\
\hline
\end{tabular}




\section{Bivariate correlation}

Bivariate correlation between the two variables provides basic ground for relationship measurement. Table 4 depicts the correlation matrix between dependent and independent variables of this study. There is a strong evidence of a close correlation between growth and growth factors [including time interval $(T)$ and population $(M)$ ] specific for this research.

The findings from Table 4 suggests that growth $(r=.905, p=.000)$ is significantly correlated with time results $(r=905, p=.000)$ and population results $(r=.888$, $p=.000)$. Therefore, a significant relationship exists between growth and time.

These are the indicators that variation in internal and external indicators can bring the significant part in the development of Islamic financial system.

Moreover, some of these correlations results could be examined and interpret more rigorously by structural equation model.

\section{Structural equation model}

After exploring the data reliability and validity scores, next phase is to explain the dimensionality of the constructs. The measurement model for Pakistani dataset is presented in Appendix: Fig. 3. Structural equation modeling is a combination of exploratory factor analysis (EFR) and multiple regressions [62]. However, SEM is best for confirmatory factor analysis (CFA) [56]. In this part, model measurement with the AMOS software being done to estimate and assess the constructed model of this study. First, a model for dataset was specified.

Using the PLS diagram, all the parameter estimates were measured for the underlying dataset (Appendix). Major phases of confirmatory factor analysis used for this model are: specification, identification, estimation, assessment and re-specification within model specification by mediating variables.

For the structural equation modeling, 7 observed variables (time, return, population GDP, banking assets, NAV of equity and growth of Islamic financial system) were used. While variables, i.e., time, return, population and GDP were exogenous variables. Endogenous variables in this study were banking assets, NAV of equity and growth with 3 error terms.

Statistically, the fit indices were proposed for different motivations. According to Hooper et al. [31], reader and reviewer get burden in the presence of a large number of research output, so researchers should be limited to few important model fit indices [31].

Table 4 Bivariate correlation

\begin{tabular}{|c|c|c|c|c|c|c|c|}
\hline & Time & Population & Return & Assets & Growth & Equity & GDP \\
\hline \multicolumn{8}{|l|}{ Time } \\
\hline Pearson correlation & 1 & $.991^{* *}$ & .319 & .085 & $.905^{* *}$ & $.620^{*}$ & -.088 \\
\hline Sig. (2-tailed) & & .000 & .339 & .805 & .000 & .042 & .798 \\
\hline \multicolumn{8}{|l|}{ Population } \\
\hline Pearson correlation & $.991^{* *}$ & 1 & .288 & .105 & $.888^{* *}$ & .598 & -.105 \\
\hline Sig. (2-tailed) & .000 & & .390 & .759 & .000 & .052 & .759 \\
\hline \multicolumn{8}{|l|}{ Return } \\
\hline Pearson correlation & .319 & .288 & 1 & -.498 & .213 & .551 & .275 \\
\hline Sig. (2-tailed) & .339 & .390 & & .119 & .529 & .079 & .413 \\
\hline \multicolumn{8}{|l|}{ Assets } \\
\hline Pearson correlation & .085 & .105 & -.498 & 1 & .322 & $-.635^{*}$ & .191 \\
\hline Sig. (2-tailed) & .805 & .759 & .119 & & .333 & .036 & .573 \\
\hline \multicolumn{8}{|l|}{ Growth } \\
\hline Pearson correlation & $.905^{* *}$ & $.888^{* *}$ & .213 & .322 & 1 & .473 & .138 \\
\hline Sig. (2-tailed) & .000 & .000 & .529 & .333 & & .142 & .686 \\
\hline \multicolumn{8}{|l|}{ Equity } \\
\hline Pearson correlation & $.620^{*}$ & .598 & .551 & $-.635^{*}$ & .473 & 1 & -.159 \\
\hline Sig. (2-tailed) & .042 & .052 & .079 & .036 & .142 & & .641 \\
\hline \multicolumn{8}{|l|}{ GDP } \\
\hline Pearson correlation & -.088 & -.105 & .275 & .191 & .138 & -.159 & 1 \\
\hline Sig. (2-tailed) & .798 & .759 & .413 & .573 & .686 & .641 & \\
\hline
\end{tabular}

*Correlation is significant at the .05 level (2-tailed)

${ }^{* *}$ Correlation is significant at the .01 level (2-tailed) 
In most literature, goodness-of-fit index (GFI), Bentler's comparative fit index (CFI) and root mean square error of approximation (RMSEA) were used to estimate and evaluate the fit statistics indices for a data [32]. The fit indices of structural equation modeling reported for this study are depicted in Table 5.

The correlation relationship structure between error terms and independent variables of the analysis was suggested for a good model fit. First, model was specified with 10 variables. Ten variables were included for SEM model. The square variables (time, return, population, GDP, banking assets, equity, and growth) represent the observed variables and the circles $(e 1, e 2$, and $e 3)$ explain the error terms. The number of exogenous variables was

Table 5 The fit indices of structural equation modeling reported for underlying study. Source: Saleh [55], Hooper et al. [31], Fan et al. [23]

\begin{tabular}{ll}
\hline Level of model fit & $\begin{array}{l}\text { Recommended } \\
\text { for further analysis } \\
\text { if }\end{array}$ \\
\hline $\begin{array}{l}\text { Relative Chi square to degree of freedom } x^{2} / \mathrm{df} \\
\text { (CMIN/DF) }\end{array}$ & $>2$ \\
Goodness-of-fit index (GFI) & $<.90$ \\
Normed fit index (NFI) & $<.90$ \\
Incremental fit index (IFI) & $<.90$ \\
Tucker-Lewis index (TLI) & $<.90$ \\
Comparative fit index (CFI) & $<.90$ \\
Root mean square error of approximation (RMSEA) & $>.05$ \\
\hline
\end{tabular}

7 while many endogenous variables were 3 . The input data have 297 observations while to interpret data precisely, 37 missing values were replaced with zero value. To test and interpret the structural model fit for data, the path diagram, with standardized regression coefficients, was developed. Figure 2 illustrates the model specified for good model fit.

The correlation of error terms is a feasible solution for the model fit $[5,25,31]$. Therefore, error term correlation of $e 1$ and $e 2$ was specified for the model.

The model of dataset was identified with $d f$ of 6 .

No. of observations - no. of parameters $=$ degree of freedom

Degrees of freedom

$(28-24)=4$

The threshold for indices and correlation of data was suggested by AMOS. Variables including, GDP and return, time and population and residuals of variables $e 1$ and $e 2$ were correlated.

To test and interpret the structural model fit for data, the path diagram, including 24 parameters with standardized regression coefficients was developed.

The resulted significant path of the coefficient is with:
Return and asset (.003)
GDP and growth (.05)
Time and growth (.02)
Return and equity (.02)

Assets and growth $(.000 *)$

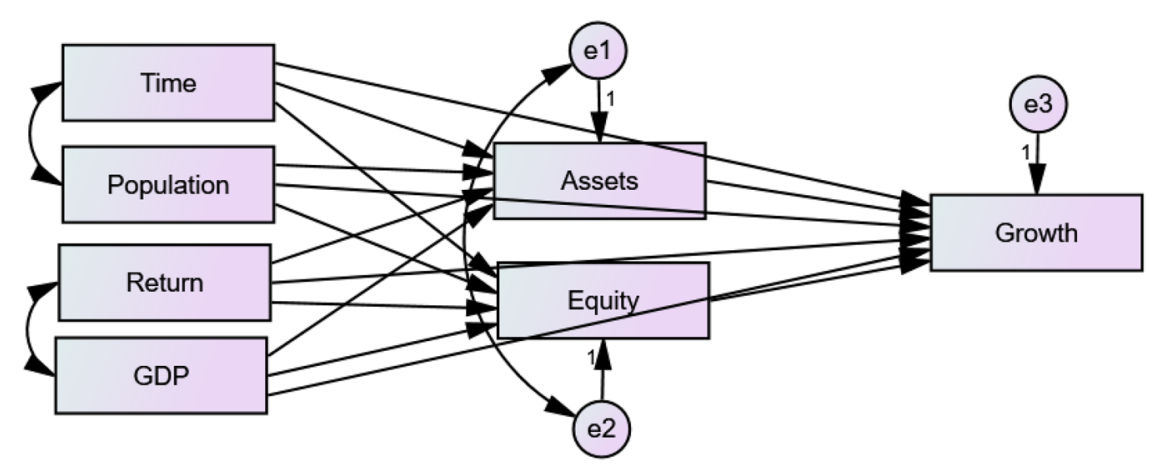

Relationship of exogenous and endogenous variables in a model of underlying study

Fig. 2 Specified model 
Equity and growth (.002)

While all the variables were significant at a level of $.001^{*}$ and .05 , respectively.

To report the hypothesized path, a model of Pakistani group was fulfilling the model fit requirement. The Chi square value of 2.025 and probability level above .05 specify a better model. Almost all the fit indices crossed the minimum cap of good fit indices. The (CMIN/DF) with a score of .506, GFI of .949, and RMSEA of .000 are acceptable as depicted in Table 6.

\section{Predictors and mediators of Islamic finance in Pakistan}

The research objective is posted to identify the causal relationship between internal and external variables to growth variable. Results of the final model for Pakistan indicate that both direct paths and two of the eight original indirect paths are significant.

The indirect effects of the GDP and time on growth are not significant at the .05 level (.106 and .391, respectively). These findings implied that these independent variables have no indirect effects on growth variable. However, the effect of population variable on growth variable is significant at the .05 level $(p=.022)$ indicating a significant indirect effect on growth. The imbalance indirect effects of the return were found for the variable of growth. This may be due to less power than expected to detect a true indirect effect between the variables [42].

Full mediation was achieved for return and population. As the relationship between return and population was significant during the direct effect of both of these variables. The relationship was significant with growth variable by a value of .05 and .00 , respectively, but after mediation relationship was not significant with a $p$ value of .823 and .201, respectively. Partial mediation was achieved for only variable of GDP as before mediation

Table 6 Level of model fit for model

\begin{tabular}{llc}
\hline Level of model fit & $\begin{array}{l}\text { Recommended } \\
\text { for further analysis if }\end{array}$ & Model fit \\
\hline $\begin{array}{l}\text { Relative Chi square to the } \\
\text { degree of freedom } x^{2} / \mathrm{df}\end{array}$ & $>2$ & .506 \\
(CMIN/DF) & & \\
Goodness-of-fit index (GFI) & $<.90$ & .949 \\
Normed fit index (NFI) & $<.90$ & .980 \\
Incremental fit index (IFI) & $<.90$ & 1.020 \\
Tucker-Lewis index (TLI) & $<.90$ & 1.107 \\
Comparative fit index (CFI) & $<.90$ & 1.000 \\
Root mean square error of & $>.05$ & .000 \\
approximation (RMSEA) & & \\
\hline
\end{tabular}

The fit indices in the structural equation model revealed significant values of model fit, moreover, a research model is in parallel to research goals $(p=.008)$ and after mediation $(p=.05)$ the relationship was significant, however, the magnitude of beta coefficient was low after mediation $(\beta=.140)$ as compared to before mediation $(\beta=.240)$.

The statistical process to reveal relation [51], among variable of this study is determined by a number of steps (Appendix).

\section{Before the mediation}

$$
\begin{aligned}
& G(\mathrm{PK})=\beta_{0}+\beta_{1} R+\beta_{2} P+\beta_{3} T+\beta_{4} \mathrm{GDP}+\text { eit, } \\
& G(\mathrm{PK})=\beta_{0}-\beta_{1} .179-\beta_{2} .569+\beta_{3} 1.480+\beta_{4} .247+\text { eit. }
\end{aligned}
$$

\section{After the mediation}

$$
\begin{aligned}
& G(\mathrm{PK})=\beta_{0}+\beta_{1} R+\beta_{2} P+\beta_{3} T+\beta_{4} \mathrm{GDP}+\text { eit } \\
& G(\mathrm{PK})=\beta_{0}-\beta_{1} .019-\beta_{2} .592+\beta_{3} 1.089+\beta_{4} .140+\text { eit. }
\end{aligned}
$$

The SEM findings in Table 7 are presented for dataset based on standardized estimated path coefficient $\beta$ value with C.R. and $p$ value. The significance of estimated path between independent and dependent variable was decided at a significance level of $\leq .05$ to decide the significance level of the path coefficient between variables of study [17].

\section{Discussion}

Banking assets and return

The coefficients for the SEM path between financial assets and return (estimated standardized $\beta$ coefficient $=-.65$, with $p=.003$ ) in final model provide strong significant support for $\mathrm{H}_{1}$.

Table 7 Results of hypothesis

\begin{tabular}{llcrl}
\hline Hypothesis & Paths & \multicolumn{3}{c}{ SEM output: Pakistani data } \\
\cline { 3 - 5 } & & Standardized $\boldsymbol{\beta}$ & C.R. $(\boldsymbol{t})$ & $\boldsymbol{P}$ \\
\hline $\mathrm{H}_{1}$ & Assets $\leftarrow$ return & -.658 & -2.99 & .003 \\
$\mathrm{H}_{2}$ & Assets $\leftarrow$ population & .481 & .297 & .767 \\
$\mathrm{H}_{3}$ & Assets $\leftarrow$ time & -.155 & -.095 & .924 \\
$\mathrm{H}_{4}$ & Assets $\leftarrow$ GDP & .395 & 1.797 & .072 \\
$\mathrm{H}_{5}$ & Equity $\leftarrow$ return & .507 & 2.188 & .029 \\
$\mathrm{H}_{6}$ & Equity $\leftarrow$ population & -.579 & -.339 & .735 \\
$\mathrm{H}_{7}$ & Equity $\leftarrow$ time & 1.066 & .624 & .533 \\
$\mathrm{H}_{8}$ & Equity $\leftarrow$ GDP & -.280 & -1.21 & .226 \\
$\mathrm{H}_{9}$ & Growth $\leftarrow$ equity & .453 & 3.053 & .002 \\
$\mathrm{H}_{10}$ & Growth $\leftarrow$ assets & .591 & 3.779 & .000 \\
\hline
\end{tabular}


$\mathbf{H}_{\mathbf{1}}$ There is a significant relationship between the volatility of Islamic banking assets and return $(R)$.

This implied that the volatility of Islamic financial institutions return has a direct effect on the growth of financial assets of Islamic financial institutions. Thus, higher is the profitability of financial institutions, the lower the growth of assets $(-.65)$ of financial assets. This may have implied that efficiency of return is not only the only factor of asset development. However, specific geographical or territorial factors influence the asset.

These results strengthen the conceptual theories of the literature. It is consistent with the findings of $[40,58]$. These results also validate that regardless of religious factors as stressed in Islamic finance literature, the efficiency of macroeconomic factors is also important to boost the growth of Islamic financial system. This also implied that bigger share of the overall industry likewise implies more strength to the bank of controlling the costs and benefits it offers to keep customers [28].

Moreover, this finding also elaborates that institutional effort for measures of increase profitability can strengthen the size of the institution as well. Thus, these results empirically proved the relationship of return and asset to influence the outward operations of the institutions.

\section{Banking assets and population}

The coefficients for the SEM path between financial assets and population (estimated standardized $\beta$ coefficient .48), with non-significant value $p=.76$, did not support the hypothesis $\mathrm{H}_{2}$.

$\mathbf{H}_{2}$ Muslim population $(P)$ has a direct effect on Islamic banking assets.

The result of final model for the relationship between asset and population is not according to expectations. This implied that the percentage of Muslims in a particular geographical area has no impact on increasing the size of Islamic financial institutions.

The research study strengthens the conceptual theories of the literature related to the relationship between assets and population. These findings are consistent with [22], that analyzes the effect of religion on Islamic Finance. The study observed that Muslims belittled Islamic banks in view of the religious variable, as well as more due to the profits, got from investments. These results also validate that regardless of religious factors, the efficiency of other factors of growth are important to boost the growth of Islamic financial system.
However, these findings are inconsistent with the finding of [4], who considered to religious factor as an important factor to attract Muslim investors and increase the institutional size.

\section{Banking assets and time interval}

The beta coefficients for the SEM path between variables of financial assets and time interval (estimated standardized $\beta$ coefficient -.15 ), with non-significant value $p=.924$, did not support the hypothesis $\mathrm{H}_{3}$.

$\mathbf{H}_{3}$ Time interval $(T)$ has a direct effect on Islamic banking assets.

The result of final model for the relationship between asset and time interval is quite unique. This implied that the matter of time on Islamic institutions has no impact on increasing and decreasing the size of assets of Islamic financial institutions.

The research study strengthens the already studied conceptual theories of the literature related to the relationship between assets and time interval that considered management expertise and other variables as an important factor to increase the share of Islamic finance in the financial system. These empirical research findings also impact the confidence of investors. So far, this study signifies the invaluable relationship of time and asset. The sample characteristics and complexity of SEM model to measure the variables may be a cause of such findings [55].

These results also validate that instead of time factors, efficiency and effectiveness of other factors of growth are important to boost the growth of Islamic financial system.

However, these findings are inconsistent with the finding of [21], who considered to the passage of time as a meaningful variable to get deep insight into determinants of growth of financial indicators and increase the institutional size. Moreover, SEM model specifies the direct significant relationship between time and growth with a significance value of $p=.02$. This finding rejects the mediating role of products and services to strengthen the relationship between time and growth of IF.

\section{Banking assets and GDP rate}

Gross domestic product (GDP) and economic development are usually related to defining financial premises. A huge amount of literature discussed the relationship between an increase in the percentage of bank deposits to GDP [10, 24, 47, 48, 59]. Moreover, SEM model specifies the direct significant relationship between GDP and growth with a significance value of $p=.000$. 
However, the hypothesized relationship between asset and GDP (estimated standardized $\beta$ coefficient .39), of this study is not significant at a level of .05. The findings of SEM model did not support the $\mathrm{H}_{4}$. This finding rejects the mediating role of products and services to strengthen the relationship between GDP and growth of IF.

$\mathbf{H}_{4}$ GDP (D) has a direct effect on Islamic banking assets.

The result of final model for the relationship between asset and GDP is also quite unique. This implied that the external environment factor, GDP, has no impact on increasing and decreasing the size of assets of Islamic financial institutions.

The research study did not strengthen the already studied conceptual theories of the literature related to the relationship between assets and GDP. The study implied that economic indicators have a no influence on investors' confidence and development of assets.

These results also validate that instead of GDP, efficiency and effectiveness of other factors of growth need to be evaluated to study their impact on assets of IFIs. Moreover, SEM model specifies the direct significant relationship between GDP and growth with a significance value of $p=.05$. This finding rejects the mediating role of products and services to strengthen the relationship between time and growth of IF.

\section{Islamic equity fund and return}

The coefficients for the SEM path between IEF and return (estimated standardized $\beta$ coefficient .50, with $p=.02$ ) in final model provide strong significant support for $\mathrm{H}_{5}$.

$\mathbf{H}_{5}$ There is a significant relationship between the volatility of NAV of Islamic equity funds and return $(R)$.

This implied that the volatility of Islamic financial institutions return has a direct effect on the growth of IEF sector. Thus, higher is the profitability of Islamic financial institutions, the greater the value of IEF. One percent increase in return leads to $.50 \%$ increase in the value of IEF. This may have implied that efficiency of return is an important factor of IEF development.

These results strengthen the previous conceptual theories of the literature built by many authors. Many authors including $[37,46]$ concluded positive results towards the performance of Islamic equity fund $[37,45]$. These results also validate that regardless of external factors, the efficiency of internal factors are also important to boost the growth of financial assets. This also implied that bigger size of the overall industry likewise implies more strength to the specific sector of an industry. However, these finding opposed to Bashir and Nawang [10] that contend the negative performance of IEF.

This finding also elaborates that industrial effort for measures of increase profitability can strengthen the size of the institution as well. These results empirically proved the relationship of return and IEF to influence the outward operations of the institutions. Moreover, these finding shows the confidence of Islamic finance investors towards IEF.

\section{Islamic equity fund and population}

The coefficients for the SEM path between IEF and population (estimated standardized $\beta$ coefficient -.57 ), with non-significant value $p=.735$, did not support the hypothesis $\mathrm{H}_{6}$.

$\mathbf{H}_{6}$ Population $(P)$ has a direct effect on NAV of Islamic equity funds.

The result of final model for the relationship between IEF and population is not according to expectations. Again, this implied that the percentage of Muslims in a particular geographical area has no impact on increasing the size of IEF. This inferred the importance of creating awareness about Islamic products and services to people of Pakistan [48].

The research study strengthens the conceptual theories of the literature related to the relationship between IEF and population. Again, these findings are consistent with Erol and El-Bdour [22], that analyzes the effect of religion on investment in Islamic products and services [22].

However, these findings are inconsistent with the finding [6], the researcher contends that the growing population of Muslims in a world is considered an important force behind establishment and growth of Islamic finance products and services $[6,33]$.

These results also validate that regardless of religious belief factors, the efficiency of other factors of growth are important to boost the growth of Islamic products and services in Pakistan.

\section{Islamic equity fund and time interval}

The beta coefficients for the SEM path between variables of IEF and time interval (estimated standardized $\beta$ coefficient 1 ), with non-significant value $p=.533$, did not support the hypothesis $\mathrm{H}_{3}$.

$\mathbf{H}_{7}$ Time interval $(T)$ has a direct effect on NAV of Islamic equity funds. 
The result of a modified model for the relationship between IEF and time interval is not according to expectations. This implied that the matter of time on Islamic institutions have no impact on increasing and decreasing the size of investment of IEF.

These findings are inconsistent with the finding of Elfakhani et al. [21], who considered to the passage of time as a meaningful variable to get deep insight into determinants of growth of financial products and services [21]. Moreover, SEM model specifies the direct significant relationship between time and growth with a significance value of $p=.02$. This finding rejects the mediating role of IEF to strengthen the relationship between time and growth of IFIs.

These empirical research findings also revealed the confidence of investors. Research finding indicates that investors have no confidence on IEF. So far, this study signifies the invaluable relationship of time and IEF. These results also validate that instead of time factors, efficiency and effectiveness of other factors might have an impact on the growth of Islamic equity funds.

However, results of bivariate correlation implied a significant relationship between IEF and return with a $p$ value of .04 . While the beta coefficient of .620 presented a positive relationship between the variables, i.e., increase in return lead to increase in investments in IEF. These results also validate that instead of time factors, efficiency and effectiveness of other factors of might have an impact on the growth of Islamic equity funds.

\section{Islamic equity fund and GDP rate}

As depicted in Table 7, the hypothesized relationship between IEF and GDP (estimated standardized $\beta$ coefficient $=-.28$ ) of this study is not significant at a level of .05 with a $p$ value of .22 . The findings of SEM model did not support the $\mathrm{H}_{8}$.

$\mathbf{H}_{\mathbf{8}}$ GDP (D) has a direct effect on NAV of Islamic equity funds.

The result of final model for the relationship between IEF and GDP is unexpected. This implied that the external environment factor, GDP, have no impact on increasing and decreasing the size of investment in Islamic equity fund.

The research study did not strengthen the already studied conceptual theories of the literature including Nguena [49] that is related to the relationship between Islamic products and GDP [49]. The study implied that GDP, an economic indicator of growth, has a no influence on investors' confidence and development of IEF. Moreover, SEM model specifies the direct significant relationship between GDP and growth with a significance value of $p=.05$. This finding rejects the mediating role of IEF to strengthen the relationship between time and growth of IF.

However, this research finding is consistent with Johnson [36] that refused the impact of GDP on the growth of Islamic financial products and services [36, 37].

These results also validate that instead of GDP, efficiency and effectiveness of other macroeconomic factors of growth need to be evaluated to study their impact on the growth of Islamic financial system.

\section{Islamic equity fund and growth of Islamic finance}

The coefficients for the SEM path between financial assets and growth variable of IF (estimated standardized $\beta$ coefficient .453, with $p=.002$ ) in final model provide strong significant support for $\mathrm{H}_{9}$.

$\mathbf{H}_{\mathbf{9}} \quad$ NAV of Islamic equity funds has a direct effect on the growth of Islamic financial system.

This implied that the increase in investment in IEF has a direct effect on the growth of Islamic financial institutions. Thus, higher is the confidence of investors on IEF, the greater the growth of equity fund of Islamic financial institutions. One percent increase in IEF leads to .453 percent increase in IF. This further implied that variable of IEF of this study conferred that variable of growth in IEF is an important factor of overall IF development.

These results strengthen the conceptual theories of the previous literature. It is consistent with the findings of $[34,37]$. These results also validate the impact of institutional products and services to the profitability of the overall industry. This also implied that bigger level of investment of IEF has a positive impact on the overall industry and likewise implies more strength to the Islamic financial institutions.

These results empirically proved the relationship of growth of IEF and IF to influence the outward operations of the institutions.

\section{Banking assets and growth of Islamic finance}

The coefficients for the SEM path between financial assets and growth variable of IF (estimated standardized $\beta$ coefficient $=.59$, with $p=.000$ ) in final model provide strong significant support for $\mathrm{H}_{10}$.

$\mathbf{H}_{10}$ Islamic banking assets have a direct effect on the growth of Islamic financial system.

This implied that the increase in the volume of financial assets has a direct effect on the growth of Islamic financial institutions. Thus, higher are the assets of financial institutions, the greater the growth of assets of financial 
assets. One percent increase in assets leads to .59 percent increase in IF. This further implied that variable of an asset of this study conferred that assets are an important factor of overall IF development.

These results strengthen the conceptual theories of the previous literature. It is consistent with the research findings of studies including [12, 45]. These results also validate the impact of an internal factor of growth to the growth of financial institutions profitability. This also implied that bigger volume of the assets has a positive impact on overall industry likewise implies more strength to the Islamic financial institutions. This result empirically proved the relationship of growth of asset and IF to influence the outward operations of the institutions.

\section{Conclusion}

Many contemporary study's findings suggest 'Islamic Finance' as an effective means to build an inclusive financial system for economic growth. Today, Islamic financial assets grow at 15-20\% a year in most core markets of all over the world and 3.3\% of global banking assets. The study of development factors has become progressively emerged in last few decades with the introduction of Islamic financial economics globally. This has boosted perception and awareness among depositors and investors to include ethical preferences in their savings and business motives.

This study confirmed the mediating role of banking assets and IEFs in strengthening the relationship between return and growth of IF system. The results of the SEM final model indicated that the $\mathrm{H}_{1}, \mathrm{H}_{5}, \mathrm{H}_{9}$, and $\mathrm{H}_{10}$ are supported, $\mathrm{H}_{1}$ is accepted, i.e., there is a significant relationship that influences profitability measuring return with the dependent variable of financial assets. For $\mathrm{H}_{5}$, there is a significantly close relationship between variables of the dataset that influence IEF investment with an independent variable which is the return of financial institutions with significance at level 5\%. Overall, 4 paths in the final model were found to be significant. However, the study is failed to support the significant impact of a return to the asset, population to assets, time to assets, GDP to assets, population to equity, time to equity and GDP to equity.

This study provides a useful knowledge of the factors that might have an impact and contribution to the successful adoption of an Islamic financial system in organizations. However, the scope of this study is limited to the financial system of Pakistan. The discussion can be expanding by comparing the growth of different countries with roughly the same variables. Small sample size prevents from performing rigid analysis on the sample frame. It is required to use more advanced application of statistics, such as Monte Carlo simulation, or probability simulation for more useful findings. Another limitation of this research was a low reliability $(<.6)$ of some variables. These results might lead to a large number of explanations. Probably, such a relatively low-reliability results $(<.6)$ is because of the respondent's different background more specifically sample characteristics that differentiate one variable to another one.

\section{Implications}

This study will help to extend the dimensions of debate in a sector of Islamic banking and finance at different levels. First, according to author knowledge, this is an explicit study in relation to the analysis of environmental factors of Pakistan in a sector of Islamic finance. As this study not only investigated the impact of development factors on a general level but also opened a way for future research in a specific direction.

Due to time constraints and difficulties to specify an approach to performance measurement, previous author studies were restricted to analyze the detailed information on traditional statistical models. This paper explains the impact of environmental factors and nature of work on the efficiency of Islamic financial industry. This study explores the new approach relating to the identification of performance of Islamic industry framework in the context of Pakistan. The institutional performance in relation to the direct impact of macroeconomic variables is being studied. Indeed, many authors worked on this issue [13$15,44]$. However, like other studies, these studies did not explore the impact of mediating role of Islamic products and services on Islamic finance. This research used a time series data for 11 years that covered Islamic banks and Islamic investment institutions including internal and external environmental development factors of growth.

Second, Islamic products and services are developed on the basis of Shariah compline principles. The examination of development factors influencing the Islamic financial institutions provides an insight to learn about difficulties arising from specific environmental factors.

Third, the relationship between internal and external development factors with the performance of Islamic finance provides the strength to current Islamic agency principle contracts significance. The findings of paper generated greater awareness among organizations of Pakistan on the importance of strengthening the current Islamic financial system as a vehicle for organizational effectiveness.

The empirical findings of this research conferred the impact of significant development factors to strengthen the relationships and control the barriers to Islamic finance industry growth. Managers and regulators of IF industry should take a timely action to enhance the efficiency of existing services of financial institutions $[47,48]$. 
This study shows that the industrial products and services getting momentum and at a level to give strong support to Islamic financial system. However, certain internal factor, i.e., the level of profitability, has a significant position to influence the Islamic finance industry. This signifies the strong role of profitability to develop the Islamic finance industry in Pakistan. Pakistani financial institutions shall conceive a better strategy of products introduced to get a return performance.

The size and quantity of Islamic products are crucial for the growth of IF. The policies and strategies should be implemented to develop the confidence of stakeholders. The managers should have focused on research and development to fulfill the market requirements. This can help to attract new investors and keep the confidence of potential investors. The management should increase the outreach of Islamic products and services to the new and potential customer. The big financial institution with a big pan of operations must implement strategies to innovate new products.

The policies should be developed to encourage investors to invest in IEFs. The implication for practician in the Islamic financial system is that development of financial services is achieved when there is an improvement in fulfilling market needs and wants. An IEF and financial assets were significantly correlated with the annual growth of IFS in a dataset. This shows that innovative, market requirement is still regarded as an important factor.

\section{Abbreviations}

IB: Islamic bank; IEF: Islamic equity finance; IF: Islamic finance; IFI: Islamic financial institution; IFI's: Islamic financial institutions; SEM: structural equation modeling.

\section{Acknowledgements}

Huma Nawaz gratefully acknowledges the PHD research supervisor Prof. Dr. Barjoyai Bin Bardai of Al-Madinah International University MEDIU, Malaysia for guidance, and encouragement for carrying out this study.

\section{Authors' contributions}

$\mathrm{HN}$ is a single author of this study. The author read and approved the final manuscript.

\section{Funding}

Funding information is not applicable.

\section{Availability of data and materials}

The datasets used and/or analyzed during the current study are available from the corresponding author on reasonable request.

\section{Competing interests}

The author declares that there are no competing interests.

\section{Author details}

${ }^{1}$ Al-Madinah International University MEDIU, Kuala Lumpur, Malaysia. ${ }^{2}$ Islamia University Bahawalpur, Bahawalpur, Pakistan.

\section{Appendix}

Summary of statistical analysis for Pakistani dataset

$$
\begin{aligned}
& \mathrm{IB}(\mathrm{PK})=\beta_{0}+\beta_{1} R+\beta_{2} P+\beta_{3} T+\beta_{4} \mathrm{GDP}+\text { eit } \\
& \mathrm{IB}(\mathrm{PK})=\beta_{0}-\beta_{1} .65+\beta_{2} .48-\beta_{3} .15+\beta_{4} .39+\text { eit } \\
& E(\mathrm{PK})=\beta_{0}+\beta_{1} R+\beta_{2} P+\beta_{3} T+\beta_{4} \mathrm{GDP}+\text { eit } \\
& E(\mathrm{PK})=\beta_{0}+\beta_{1} .50-\beta_{2} .57+\beta_{3} 1-\beta_{4} .280+\text { eit } \\
& G(\mathrm{PK})=\beta_{0}+\beta_{1} I B(\mathrm{PK})+\beta_{2} E(\mathrm{PK})+\text { eit } \\
& G(\mathrm{PK})=\beta_{0}+\beta_{1} .591+\beta_{2} .453+\text { eit } \\
& G(\mathrm{PK})=\beta_{0}+\beta_{1} R+\text { eit } \\
& G(\mathrm{PK})=\beta_{0}+\beta_{1} P+\text { eit } \\
& G(\mathrm{PK})=\beta_{0}+\beta_{1} T+\text { eit } \\
& G(\mathrm{PK})=\beta_{0}+\beta_{1} \mathrm{GDP}+\text { eit } \\
& M_{e} \mathrm{IB}(\mathrm{PK})=\beta_{0}+\beta_{1} R+\text { eit } \\
& M_{e} \mathrm{IB}(\mathrm{PK})=\beta_{0}+\beta_{1} P+\text { eit } \\
& M_{e} \mathrm{IB}(\mathrm{PK})=\beta_{0}+\beta_{1} T+\text { eit } \\
& M_{e} \mathrm{IB}(\mathrm{PK})=\beta_{0}+\beta_{1} \mathrm{GDP}+\text { eit } \\
& M_{e} E(\mathrm{PK})=\beta_{0}+\beta_{1} R+\text { eit } \\
& M_{e} E(\mathrm{PK})=\beta_{0}+\beta_{1} P+\text { eit } \\
& M_{e} E(\mathrm{PK})=\beta_{0}+\beta_{1} T+\text { eit } \\
& M_{e} E(\mathrm{PK})=\beta_{0}+\beta_{1} \mathrm{GDP}+\text { eit } \\
& G(\mathrm{PK})=\beta_{0}+\beta_{1} R+\beta_{2} M_{e} \mathrm{IB}(\mathrm{PK})+\text { eit } \\
& G(\mathrm{PK})=\beta_{0}+\beta_{1} P+\beta_{2} M_{e} \mathrm{IB}(\mathrm{PK})+\text { eit } \\
& \mathrm{G}(\mathrm{PK})=\beta_{0}+\beta_{1} T+\beta_{2} M_{e} \mathrm{IB}(\mathrm{PK})+\text { eit } \\
& G(\mathrm{PK})=\beta_{0}+\beta_{1} \mathrm{GDP}+\beta_{2} M_{e} \mathrm{IB}(\mathrm{PK})+\text { eit } \\
& G(\mathrm{PK})=\beta_{0}+\beta_{1} R+\beta_{2} M_{e} E(\mathrm{PK})+\text { eit } \\
& G(\mathrm{PK})=\beta_{0}+\beta_{1} P+\beta_{2} M_{e} E(\mathrm{PK})+\text { eit } \\
& G(\mathrm{PK})=\beta_{0}+\beta_{1} T+\beta_{2} M_{e} E(\mathrm{PK})+\text { eit } \\
& G(\mathrm{PK})=\beta_{0}+\beta_{1} \mathrm{GDP}+\beta_{2} M_{e} E(\mathrm{PK})+\text { eit }
\end{aligned}
$$

Initial finding: measurement model for Pakistani dataset See Figs. 3 and 4. 

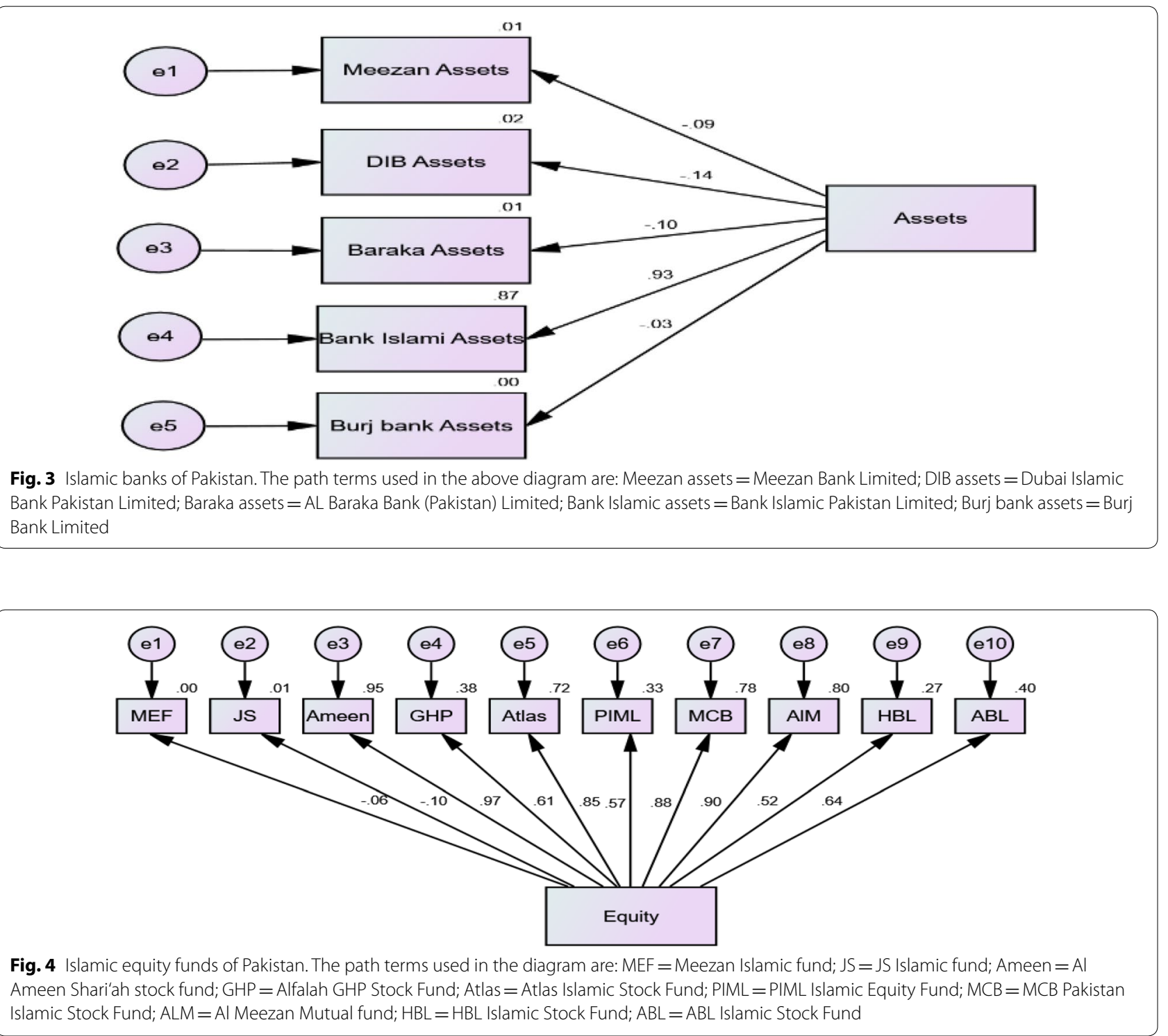

Received: 3 August 2019 Accepted: 23 October 2019

Published online: 14 November 2019

\section{References}

1. Abdullah RFS, Rahman ARA (2007) Factors influencing knowledge of Islamic banking services: the case of Malaysian bank managers. Rev Islam Econ 11:31

2. Adebola SS, Yusoff WSW, Dahalan J (2011) The impact of macroeconomic variables on Islamic banks financing in Malaysia. Res J Finance Account 2:22-32

3. Akhtar MF, Ali K, Sadaqat S (2011) Liquidity risk management: a comparative study between conventional and Islamic banks of Pakistan. Interdiscip J Res Bus 1:35-44

4. Amin M (2009) Would Islamic finance have prevented the global financial crisis? New Horiz 173:40-44

5. Anderson JC, Gerbing DW (1984) The effect of sampling error on convergence, improper solutions, and goodness-of-fit indices for maximum likelihood confirmatory factor analysis. Psychometrika 49:155-173
6. Arabi A (2008) Submitted to. Kdi school of public policy and management

7. Azhar Rosly S, Afandi Abu Bakar M (2003) Performance of Islamic and mainstream banks in Malaysia. Int J Soc Econ 30:1249-1265

8. Balala MH (2011) Islamic finance and law: theory and practice in a globalized world. Tauris, London

9. Barbieri K, Keshk OM, Pollins BM (2009) Trading data: evaluating our assumptions and coding rules. Confl Manag Peace Sci 26:471-491

10. Bashir MS, Nawang WRW (2011) Islamic and conventional unit trusts in Malaysia: a performance comparison. J Islam Econ Bank Finance 7:4

11. Bidabad B, Allahyarifard M (2008) Efficiency of assets and liabilities management in Islamic banking system. J N Econ Commer 3:109-128

12. Bourke $P$ (1989) Concentration and other determinants of bank profitability in Europe, North America and Australia. J Bank Finance 13:65-79

13. Brown K, Hassan MK, Skully M (2007) 7 Operational efficiency and performance of Islamic banks. Handbook of Islamic banking. Edward Elgar Publishing, Cheltenham, p 96

14. Brown K, Skully M (2006) Ethical investments and performance of Islamic banks. J Islam Econ Bank Finance 5:61-72 
15. Brown K, Skully M (2007) Islamic banks from a global perspective. J Islam Econ Bank Finance 3:105-133

16. Bryman A, Bell E (2007) Business research strategies. Business research methods. Oxford University Press, Oxford

17. Byrne B (2001) Structural equation modeling with AMOS: basic concepts, applications, and programming. Lawrence Erlbaum Associates, Rahway

18. Cant RG (1975) Socio-economic indicators: theories and applications. Int Soc Sci J XXVII(1):190-194

19. Carr-Lee KG (2013) Master of public policy in public policy. Citeseer

20. Creswell JW, Plano Clark VL, Gutmann ML, Hanson WE (2003) Advanced mixed methods research designs. Handbook of mixed methods in social and behavioral research. Sage, Thausand Oaks, pp 209-240

21. Elfakhani S, Hassan MK, Sidani Y (2005) Comparative performance of Islamic versus secular mutual funds. In: 12th economic research forum conference in Cairo, Egypt. pp 19-21

22. Erol C, El-Bdour R (1989) Attitudes, behaviour, and patronage factors of bank customers towards Islamic banks. Int J Bank Mark 7:31-37

23. Fan $X$, Thompson B, Wang L (1999) Effects of sample size, estimation methods, and model specification on structural equation modeling fit indexes. Struct Equ Model Multidiscip J 6:56-83

24. Furqani H, Mulyany R (2009) Islamic banking and economic growth: empirical evidence from Malaysia. J Econ Cooperation Dev 30:59-74

25. Gerbing DW, Anderson JC (1984) On the meaning of within-factor correlated measurement errors. J Consum Res 11:572-580

26. Hair J et al (1995) Multivariate data analysis with readings. Prentice Hall, Englewood Cliffs

27. Haron S (1996) Competition and other external determinants of the profitability of Islamic banks. Islam Econ Stud 4:49-66

28. Haron S (2004) Determinants of Islamic bank profitability. Glob J Finance Econ 1:11-33

29. Hau KT, Marsh HW (2004) The use of item parcels in structural equation modelling: non-normal data and small sample sizes. Br J Math Stat Psychol 57:327-351

30. Hegazy WS (2006) Contemporary Islamic finance: from socioeconomic idealism to pure legalism. Chic J Int Law 7:581

31. Hooper D, Coughlan J, Mullen M (2008) Structural equation modelling: guidelines for determining model fit. Electron J Bus Res Methods 6:53-60

32. Hulland J, Chow YH, Lam S (1996) Use of causal models in marketing research: a review. Int J Res Mark 13:181-197

33. Imam PA, Kpodar K (2010) Islamic banking: how has it diffused?. International Monetary Fund, Washington, D.C

34. INC FI (2002) Re: Islamic equity funds, an analysis of the current state of an industry

35. Jick TD (1979) Mixing qualitative and quantitative methods: triangulation in action. Adm Sci Q 24:602-611

36. Johnson K (2013) The role of Islamic banking in economic growth

37. Kamil NK, Alhabshi SO, Bacha OI, Masih M (2014) Heads we win, tails you lose: is there equity in Islamic equity funds? Pac Basin Finance J 28:7-28

38. Khan A (2014) Sharia stock index and economic activity in Malaysia: is there a connection? J Islam Econ Bank Finance 113:1-6

39. Khan ZH, Watson PJ (2006) Research:"construction of the Pakistani religious coping practices scale: correlations with religious coping, religious orientation, and reactions to stress among Muslim university students". Int J Psychol Relig 16:101-112

40. Kuo T, Wu A (2007) The determinants of organizational innovation and performance: an examination of Taiwanese electronics industry. SSRN Electron J. https://doi.org/10.2139/ssrn.921324

41. Loan FA (2012) Impact of the internet surfing on reading practices and choices. Webology 9:1-10

42. Mackinnon DP, Lockwood CM, Williams J (2004) Confidence limits for the indirect effect: distribution of the product and resampling methods. Multivar Behav Res 39:99-128
43. Moin MS (2008) Performance of Islamic banking and conventional banking in Pakistan: a comparative study. Dissertation, University of Skövde, Skövde

44. Moisseron JY, Moschetto BL (2014) Islamic finance: a review of the literature. Int Bus Econ Res J 14:745-762

45. Molyneux P, Thornton J (1992) Determinants of European bank profitability: a note. J Bank Finance 16:1173-1178

46. Nainggolan YA (2011) Taking a leap of faith: are investors left short changed?

47. Nawaz H, Bardai B (2017) Profitability of Islamic banks: case of Malaysia. J Islam Bank Finance 34(3):90-103

48. Nawaz H, Bardai B (2017) Perceptions and acceptance of Islamic banking in Pakistan. Int Sci Manag J 2:1-14

49. Nguena CL (2013) Inclusive and pro-poor financial system in Africa: does Islamic finance development matter?. Association of African Young Economists, Yaoundé

50. Nienhaus V (1983) Profitability of Islamic PLS banks competing with interest banks: problems and prospects. J Res Islam Econ 1:37-47

51. Preacher KJ, Hayes AF (2008) Asymptotic and resampling strategies for assessing and comparing indirect effects in multiple mediator models. Behav Res Methods 40:879-891

52. Rani S, Sikka G (2012) Recent techniques of clustering of time series data: a survey. Int J Comput Appl. https://doi.org/10.5120/8282-1278

53. Roy DA (1991) Islamic banking. Middle East Stud 27(3):427-456

54. Sadeghi M (2008) Financial performance of Shariah-compliant investment: evidence from Malaysian stock market. Int Res J Finance Econ 20:15-26

55. Saleh MA (2006) Antecedents of commitment to an import supplier. Queensland University of Technology Brisbane, Brisbane

56. Schreiber JB, Nora A, Stage FK, Barlow EA, King J (2006) Reporting structural equation modeling and confirmatory factor analysis results: a review. J Educ Res 99:323-338

57. Series OO (2012) Islamic finance in OIC member countries. Kuwait: OIC outlook series

58. Shahimi S, Ismail A, Ahmed S (2006) A panel data analysis of fee income activities in Islamic banks. Islam Econ 19:23-35

59. Shaikh SA (2011) An ideal Islamic economic system: a gone case? J Islam Econ Bank Finance 113:1-4

60. Siddiqui AA (2013) Islamic banking industry-growing amid challenges. J Islam Bank Finance 30:13-18

61. Subramaniam A, Al Mamun A, Permarupan PY, Zainol NRB (2014) Effects of brand loyalty, image and quality on brand equity: a study among bank islam consumers in Kelantan, Malaysia. Asian Soc Sci 10:67

62. Tabachnick BG, Fidel LS, Osterlind SJ (2001) Using multivariate statistics. Allyn and Bacon, Boston

63. Vogel FE, Hayes SL (1998) Islamic law and finance: religion, risk, and return. Brill, Leiden

64. Williams B, Onsman A, Brown T (2010) Exploratory factor analysis: a fivestep guide for novices. Australas J Paramed 8:1-13

65. Wilson R (2011) Islamic banking and finance in North Africa past develop ment and future potential. African Development Bank, Tunis-Belvedère

66. Zikmund WG (2003) Business research methods, mason, Ohio, southwestern. $X$ the restaurant behaviour of the Berlin people

\section{Publisher's Note}

Springer Nature remains neutral with regard to jurisdictional claims in published maps and institutional affiliations. 